\title{
Testing the methodology for analyzing the impact of wages on the reproduction of cadres in rural areas by the example of urban districts of the Sverdlovsk region
}

\author{
V. M. Sharapova ${ }^{1}$, I. A. Borisov ${ }^{2}$, N. V. Sharapova ${ }^{2 匹}$ \\ ${ }^{1}$ Ural State Agrarian University, Ekaterinburg, Russia \\ ${ }^{2}$ Ural State Economic University, Ekaterinburg, Russia \\ 凶E-mail:sharapov.66@mail.ru
}

\begin{abstract}
The purpose of this article is to develop and test a methodology for assessing the impact of wages on the reproduction of personnel in rural areas. Urban districts of the Sverdlovsk region were selected as the object for the pilot project. As a research method, the authors used multiple regression analysis of spatial data using the least squares method. As the data sources for the sample, data from the database of the municipalities of Rosstat were used. As a result of the behavioral research, key factors were identified that affect various indicators of the reproduction of the labor resources of the territory, the statistical significance of the influencing factors is evaluated, and the explanatory ability of the obtained models of their possibilities of their use for forecasting is evaluated. It was found that indicators of wages have a significant impact on most indicators of the reproduction of labor resources, indicators of the state of public health in the territory also have a significant impact. Based on the results of the study, recommendations are given for further refinement of the methodology, as well as recommendations for improving the system of statistical reporting of municipalities. The scientific novelty of the study is the use of regression analysis as a method for assessing the reproductive processes of rural territories using data from urban districts of the Sverdlovsk region. The practical significance of the results obtained is a quantitative assessment of the dependence of the reproduction parameters on the factors under study, which makes it possible to quantify the economic effect of the predicted measures. Also, the practical significance of the article lies in identifying the advantages and disadvantages of the proposed methodology that emerged during the pilot study, and the corresponding directions for its improvement.
\end{abstract}

Keywords: reproduction of labor resources, rural territories, movement of labor resources of the territory, labor market, human capital.

For citation: Sharapova V. M., Borisov I. A., Sharapova N. V. Testing the methodology for analyzing the impact of wages on the reproduction of cadres in rural areas by the example of urban districts of the Sverdlovsk region // Agrarian Bulletin of the Urals. 2020. No. 03 (194). Pp. 91-100. DOI: ...

Paper submitted: 05.02.2020.

\section{Introduction}

Foreign experience in modeling the processes of reproduction of rural territories is formed within the framework of agricultural economics, which emerged as an independent field of economic knowledge at the beginning of the last century with the world-famous monograph by G. K. Taylor [1] in 1912. Thus, the history of modeling the processes of reproduction of labor Resource in agriculture has almost a century of history. Most actively, this area began to develop from the 19601790s. accompanied by a significant increase in empirical research using various economic and mathematical methods, primarily econometric analysis. At the same time, an essential feature of the foreign approach to the study of reproduction processes is the consideration of the various phases and aspects of the reproduction of labor resources separately at the level of adoption by the subjects of the reproduction process of specific decisions, in contrast to the comprehensive consideration of reproduction inherent in domestic economic science.
Based on the analysis of the research experience of modeling the processes of reproduction of rural personnel, it can be concluded that most foreign studies are concentrated around three main research areas. The first research area involves the analysis of various aspects of the formation of human capital in rural areas in the crayfish of the theory of human capital. The second research area involves the analysis of migration processes in rural areas, primarily the outflow of population from rural areas. The third research area involves an analysis of the demand for labor from agricultural enterprises, including the establishment of an optimal wage system.

Based on the analysis of world experience in the study of reproductive processes in rural areas, it can be concluded that the regression analysis of macro data by territory is used as the main analysis tool. The only exception is the third research area, using micro data as a data source. However, due to the complexity of obtaining micro data, this direction does not have a well-established methodology for obtaining empirical results. 
Among the most modern foreign studies, mention can be made of the work of Ardington, Cally, et al. [2], Ma, SangJin, et al. [3], Dutta, Subrata, and Subhendu Chakrabarti [4], Luong, Hy V. [5], Sagynbekova L. [6].

Among the most modern domestic works on the problem of the reproduction of labor resources in rural areas, the work of Zakshevsky V. G., Merenkova I. N. deserves mention [7], Gorbunova O. S. [8], Yugov E. A. [9], Yurzina T. A. [10], Bannikova N. V. [11], Bondarenko L. V. [12], Rakhmatullina L. I. [13], Umerova S. E. [14], Chekmareva E. A. [15], Sharipova S. A. [16].

Based on a comparison of the methodology of domestic and foreign works devoted to the problems of reproduction of labor resources, it can be concluded that domestic works usually use economic and statistical methods in research, involving an analysis of a system of interrelated socio-economic indicators. This methodology is significantly different and inferior to the methodology of foreign studies based on the use of regression analysis. At the same time, an important advantage of Russian studies is their complexity, while foreign studies are more focused on the analysis of any particular aspects of the reproduction system. Thus, there is a need to develop a comprehensive methodology for analyzing the reproduction of labor resources using the generally accepted methodology of regression analysis.

\section{Methods}

The methodology for analyzing the effect of wages on the reproduction of cadres in rural areas should satisfy the following criteria.

Firstly, the methodology should be applicable at the level of economic entities and authorities at the appropriate level, in particular, not involve additional research and additional costs.

Secondly, the methodology should correctly take into account the specifics of each territory.

Thirdly, the methodology should be based on modern scientific methods of assessment, implying the possibility of an objective assessment of the significance of the influence of various factors.

The specifics of the reproduction of cadres in rural territories is that since the rural population generally lives at a considerable distance from large cities, the local factors of each settlement have a great influence on reproduction. Moreover, significant intraregional differentiation of territories does not allow the use of regional statistics as a data source. The requirement of the feasibility of the methodology, in turn, makes it impossible to use the specific data of business entities, since such data is often not open, and sometimes not comparable. Based on this, in our opinion, the most appropriate would be the use in the development of methods of statistical reporting of municipalities. The advantage of this data type is its regularity, comparability and accessibility. At the same time, the indicated data allow taking sufficiently into account the specifics of specific territories up to the territorial division of the subject of the Russian Federation.

In our opinion, the most justified method of assessment is the use of multiple regression analysis. As a review of foreign studies on the problems of reproduction of cadres in rural areas in its various aspects shows, this method is standard for this kind of research. The advantages of this method include the ability to evaluate the explanatory ability of the model, the significance of the influence of individual factors on the parameters of reproduction, as well as its strength. A significant advantage of this type of model is the possibility of using them as a forecasting tool that evaluates the influence of various control actions on the analyzed variables with a predetermined degree of accuracy.

The complexity of the personnel reproduction process involves the use of various indicators of the reproduction process as dependent variables of the model, it should be noted that since the personnel reproduction process is an integral part of the general population reproduction process, variables characterizing the population reproduction processes should be used as dependent variables.

The characteristics of the territory should be used as independent variables, including indicators of the average wage in the territory and in sectors related to agriculture. Also, when choosing independent variables, special attention should be paid to variables that are the results of decisions made by both business entities of a given territory and municipal authorities.

In general terms, the methodology for analyzing the effect of wages on the system of reproduction of personnel involves the implementation of the following stages of the study.

The first stage involves the selection of a set of dependent variables for a given research object.

The second stage involves the selection of independent variables.

The third stage involves the assessment of a set of regression equations of the form:

$$
y=\alpha+\beta X,
$$

where $y$ - indogenious variable characterizing the reproduction process,

$X$ - vector of independent variables characterizing the state of the territory and the level of wages,

$\varepsilon$ - random error.

The fourth stage involves the determination of a set of independent variables that best explain the behavior of the corresponding dependent variable. As a selection criterion, the adjusted determination coefficient will be used, taking into account differences in the number of explanatory variables for different equations.

The fifth stage involves predicting the effect of wages on the corresponding parameters of the reproduction process using the best forms of dependence among the evaluated equations. At this stage, it is supposed to evaluate the average reaction of reproduction parameters to changes in wages and the construction of corresponding confidence intervals.

It should be noted that the final form of the methodology, including a set of explanatory variables, is individual for each object and study period.

As a pilot study, this work assumes an assessment of the impact of wages on the reproduction of personnel by the example of a sample that includes urban districts of the Sverdlovsk region.

Let's move on to the selection of a set of dependent variables. A significant problem in determining the set of dependent variables is the restrictions arising from the incompleteness of regional statistics. So, for example, the data on the average number of enterprises related, according to OKVED2, to 
the sector Agriculture, forestry, hunting, fishing, and fish farming are extremely incomplete. In fact, from 64 urban districts of the Sverdlovsk region, complete data on the number of such enterprises for 2016-2018 present only in 16 municipalities. This circumstance does not allow the use of this variable, since the insufficiency and non-representativeness of the sample will not allow us to obtain reliable conclusions on its basis.

Based on the analysis of the statistics of municipalities, the following dependent variables were selected for the study.

Variables characterizing the structure of the rural population:

1. The share of the working-age population in the total rural population in 2018 .

2 . The proportion of the population younger than working age in the total rural population in 2018 .

3 . The share of the population over working age in the total rural population in 201 .

Indicators characterizing the movement of the population on the territory of the municipality:

4. Relative migration growth, 2018.

5. The relative total population influx of the municipality in 2018 .

6 . The relative influx of the rural population of the municipality in 2018 .

7. The share of arrivals from abroad in the total number of arrivals in the municipality in 2018 .

8. The share of people who leave outside the Russian Federation in the total number of people who leave the municipality in 2018 .

9. The proportion of those who leave within the region in the total number of people who leave the municipality in 2018.

10. Total fertility rate, ppm, 2018.

11. The total mortality rate, ppm, 2018.

Let's move on to the choice of independent variables.

It should be noted that the influence of independent variables usually does not occur immediately, but with a slight delay, which allows the use of data from past periods of time in the study. Also, in order to take into account the lag in the influence, the study will use the values of explanatory variables at least 2017.

Based on the analysis of municipal statistics, the following variables were selected for the study.

Salary indicators in the municipality:

1. The average monthly salary of employees of organizations (at okved2), rubles, Section A Agriculture, forestry, hunting, fishing and fish farming, 2017.

2 . The average monthly salary of employees of organizations (in okved2), ruble, total for the types of economic activity surveyed, 2017.

Indicators of social infrastructure:

3. The share of residents in emergency residential buildings in the total population of the municipality in 2010 .

4. The proportion of the population living in us. points that do not have regular bus and (or) rail links with the administrative center of the city district, in the total population of the city district, percentage, 2017.

5. The number of consumer services facilities providing services, unit per capita, 2016

6. Attendance ratio MDOU, percentage, 2011.
7. Number of cultural and leisure facilities, unit per capita, 2017.

8. The total area of residential premises, thousand square meters, thousand square meters, per capita in 2017.

9. Number of sports facilities, total, unit per capita, 2017.

10. The share of residents in dilapidated residential buildings in the total population of the municipality in 2016 .

Indicators of economic development of the territory:

11. The volume of investments in fixed assets (excluding budgetary funds) per 1 person, ruble, 2017.

12. Area of the trading floor of retail facilities, shops, square meter per capita, 2017.

13. The share of the average number of employees (without external part-time workers) of small and medium-sized entrepreneurs in the average number of employees (without external part-time workers) of all enterprises and organizations, percentage, 2015.

14. Turnover of public catering (excluding small businesses) (by okved2), thousand rubles per capita, January - December, 2017.

15. Livestock and poultry on farms of all categories at the end of the year, cattle, head per capita, 2017.

16. Sown area of crops, hectare per capita, 2017.

17. Agricultural products (at actual prices), thousand rubles per capita, 2017.

Indicators of the health status of the territory:

Unfortunately, in the wake of optimizing the health sector for unknown reasons, indicators of the provision of public health services have ceased to be reflected in municipal statistics from 2010-2011. At the same time, it should be expected that medical care as an essential element of territorial infrastructure will have a significant impact on reproduction processes. As a result, the study includes the latest available data on the health status of the territory.

The selected variables are:

18. Number of hospital organizations (departments) of health care, unit per capita, 2011.

19. Number of hospital beds, bed per capita in 2010 .

20 . The capacity of outpatient organizations, per-shift visits, City districts of the Sverdlovsk region, the value of the indicator for the year, independent and departments as part of hospital organizations and other healthcare facilities, 2010.

21 . The number of doctors of all specialties (without dentists), people per capita, 2010.

Specific indicators of the territory:

We refer to specific indicators of the territory indicators that are not included in the considered groups of indicators, but that have a potentially significant impact on the nature of reproduction.

As such indicators in the study are used:

22. Emitted into the atmosphere of pollutants emanating from stationary sources - total, thousand tons per capita, 2017.

23 . The share of the population, who defined their nationality as Russians in 2010, in the total number of the municipality. Unfortunately, more recent data on the ethnic composition of municipalities are lacking, while at the theoretical level there is reason to believe that the predominance of ethnic minorities in settlements (on the territory) may lead to the emergence of national-specific models of reproduction, which explains the inclusion of this variable in analysis. 
24. The share of the rural population in the total population of the municipality, 2017. This indicator characterizes the specialization of settlement in the territory of the municipality.

\section{Results}

According to the results of the study, the following results were obtained.

For indicators of the structure of the rural population.

For the proportion of the working-age population:

1. Salary of enterprises related to section A of OKVED. This indicator has a steady positive effect on the share of the able-bodied population in all specifications of the model.

2 . The average wage without taking into account industry specifics does not have a significant effect, which confirms the special importance of agriculture for the economy of rural territories.

3. The indicators of social infrastructure do not have a significant impact.

4. Among the indicators of economic development, a significant impact is exerted by:

- positive impact - investment in fixed assets;
- negative impact - agricultural products per capita. The negative sign of this indicator may be explained by the lower competitiveness of territories specializing in agriculture.

5. Among the indicators of the state of health care in 2010 , the impact is exerted by:

- positive - the number of hospitals per capita in 2011;

- negative - the number of doctors per capita in 2010 .

The nature of the impact of these indicators can be explained by the characteristics of the demand for medical services of different age groups.

6. Among the specific indicators of the territory, none has a significant effect.

The results of the assessment of the regression equation are presented in table 1.

For a share of the population below working age:

1. Wage figures do not have a significant impact.

2. Among the indicators of social infrastructure, the attendance coefficient of MDOU has a significant negative effect. In our opinion, this can be explained by the presence of the problem of endogeneity and MDOU deficiency in territories with increased birth rates.

Table 1

The results of the assessment of regression equations for the proportion of the population of working age

\begin{tabular}{|c|c|c|c|c|}
\hline \multicolumn{4}{|l|}{ Final sample } & 41 \\
\hline$R$-squared & & & & 0.535597 \\
\hline Adjusted R-squared & & & & 0.469253 \\
\hline$F$-statistics & & & & 8.073105 \\
\hline Prob. (F-statistics) & & & & 0.000038 \\
\hline Variable & Coefficient & Standard error & t-statistics & Prob. \\
\hline$C$ & 0.459233 & 0.028409 & 16.16529 & 0.0000 \\
\hline $\begin{array}{l}\text { The number of hospital organizations (departments) } \\
\text { of health care, unit per capita, } 2011\end{array}$ & 579.3446 & 156.5460 & 3.700796 & 0.0007 \\
\hline $\begin{array}{l}\text { Volume of investments in fixed assets (excluding budgetary } \\
\text { funds) per } 1 \text { person, rubles, } 2017\end{array}$ & $2.22 E^{-07}$ & $6.84 E^{-08}$ & 3.250909 & 0.0025 \\
\hline $\begin{array}{l}\text { Agricultural products (at actual prices), thousand rubles per } \\
\text { capita, } 2017\end{array}$ & -0.000505 & 0.000132 & -3.831991 & 0.0005 \\
\hline $\begin{array}{l}\text { The average monthly salary of employees of organizations } \\
\text { (at okved2), ruble, Section A Agriculture, forestry, hunting, } \\
\text { fishing and fish farming, } 2017\end{array}$ & $4.67 E^{-06}$ & $1.18 E^{-06}$ & 3.964401 & 0.0003 \\
\hline $\begin{array}{l}\text { The number of doctors of all specialties (without dentists), } \\
\text { people per capita, } 2010\end{array}$ & -34.76420 & 9.777907 & -3.555383 & 0.0011 \\
\hline
\end{tabular}

people per capita, 201

Table 2

Assessment results of regression equations for the share of the population below the working age ${ }^{*}$

\begin{tabular}{|c|c|c|c|c|}
\hline \multicolumn{4}{|l|}{ Final sample } & 59 \\
\hline \multicolumn{4}{|l|}{$R$-squared } & 0.441305 \\
\hline \multicolumn{4}{|l|}{ Adjusted R-squared } & 0.388598 \\
\hline \multicolumn{4}{|l|}{ F-statistics } & 8.372790 \\
\hline \multicolumn{4}{|l|}{ Prob. (F-statistics) } & 0.000007 \\
\hline Variable & Coefficient & Standard error & t-statistics & Prob. \\
\hline$C$ & 0.317275 & 0.048196 & 6.582953 & 0.0000 \\
\hline $\begin{array}{l}\text { The number of hospital organizations (departments) } \\
\text { of health care, unit per capita, } 2011\end{array}$ & -382.0068 & 80.70349 & -4.733461 & 0.0000 \\
\hline Number of hospital beds, per capita bed in 2010 & 4.244192 & 1.801044 & 2.356518 & 0.0222 \\
\hline MDOU attendance rate, percent, 2011 & -0.154082 & 0.062644 & -2.459625 & 0.0172 \\
\hline $\begin{array}{l}\text { Livestock and poultry on farms of all categories at the end } \\
\text { of the year, cattle, head per capita, } 2017\end{array}$ & 0.047803 & 0.018729 & 2.552344 & 0.0136 \\
\hline $\begin{array}{l}\text { Livestock and poultry on farms of all categories at the end } \\
\text { of the year, cattle, head per capita, } 2017\end{array}$ & -12.44543 & 6.925426 & -1.797063 & 0.0780 \\
\hline
\end{tabular}

* Compiled by the author. 
3. Among the indicators of economic development, a significant positive effect is exerted only by the number of cattle per capita. In our opinion, this influence may indirectly reflect the higher efficiency of the livestock industry, which offers its employees greater stability as a necessary condition for raising children.

4. Among the indicators of the state of health, a significant impact is exerted by:

- negative impact - the number of hospitals and doctors;

- positive - the number of hospital beds.

In our opinion, this result is also explained by the characteristics of the age structure of demand for medical services.

5. Among the specific indicators of the territory, none has a significant effect.

The results of the assessment of the regression equation are presented in table 2 .

For a share of the population over working age, none of the factors included in the model had a significant effect.

For population movement indicators, the following results were obtained.

The following factors affect the relative total population influx of the municipality in 2018:

1. The average monthly salary of employees of organizations (in okved2), the ruble, in total for the types of economic activity surveyed, 2017, has a positive effect, which confirms a significant positive effect on the reproduction of wages.

2. Among the indicators of social infrastructure, none has a significant impact.

3. Among the indicators of economic development of the territory, a significant positive impact is exerted by the share of the average number of employees (without external parttime employees) of small and medium-sized entrepreneurs in the average number of employees (without external part-time workers) of all enterprises and organizations in 2015.

4. Among the indicators of the state of health care, the number of hospital beds per capita in 2010 has a significant positive effect. This confirms the positive contribution of the availability of medical services to reproduction.

5. Among the specific indicators of the territory, none had a significant impact.
The results of the assessment of the regression equation are presented in table 3 .

The relative influx of the rural population of the municipality in 2018 is only statistically significant: the insignificance of other indicators may indicate the peculiarities of local labor markets in rural areas, on which more zmer wages and access to jobs. In this case, small and medium-sized businesses as the most mobile subjects of labor demand provide more objective and transparent conditions for employment. In addition, it is highly likely that small and medium-sized businesses present less stringent formal requirements for candidates than large enterprises, which also increases the availability of these jobs.

The results of the evaluation of the regression equation are presented in table 4.

The following factors influence the relative migration growth in urban districts of the Sverdlovsk region in 2018 :

1 . The average monthly salary of employees of organizations (by okved2), the ruble, in total for the types of economic activities surveyed, 2017, has a positive effect, which confirms a significant positive effect on the migration attractiveness of the territory.

2. Among the indicators of social infrastructure, none has a significant impact.

3. Among the indicators of economic development of the territory:

- a significant positive impact is exerted by the share of the average number of employees (without external part-time workers) of small and medium-sized entrepreneurs in the average number of employees (without external part-time workers) of all enterprises and organizations in 2015;

- significant negative effect is exerted by the turnover of public catering (excluding small businesses) (by okved2), thousand rubles per capita, January - December, 2017.

Features The influence of the latter indicator also indirectly confirms the greater importance for the attractiveness of the territory for the development of small and medium-sized businesses and less attractive in the case of the development of large enterprises in competing industries. It is also possible that the negative coefficient of the given variable is explained by the incompleteness of municipal statistics for this indicator.

Table 3

Assessment results of regression equations for the relative total population influx of the municipality in $2018^{\star}$

\begin{tabular}{|c|c|c|c|c|}
\hline \multicolumn{4}{|l|}{ Final sample } & 64 \\
\hline \multicolumn{4}{|l|}{$\frac{R \text {-squared }}{\text { Adiusted R-sauared }}$} & 0.414976 \\
\hline Adjusted R-squared & & & & 0.385724 \\
\hline \multicolumn{4}{|l|}{$F$-statistics } & 14.18661 \\
\hline \multicolumn{4}{|l|}{ Prob. (F-statistics) } & 0.000000 \\
\hline Variable & Coefficient & Standard error & t-statistics & Prob. \\
\hline$C$ & -0.038251 & 0.004816 & -7.943289 & 0.0000 \\
\hline Number of hospital beds per capita in 2010 & 0.636236 & 0.307437 & 2.069486 & 0.0428 \\
\hline $\begin{array}{l}\text { The share of the average number of employees (without ex- } \\
\text { ternal part-time workers) of small and medium-sized entre- } \\
\text { preneurs in the average number of employees (without exter- } \\
\text { nal part-time workers) of all enterprises and organizations, } \\
\text { percentage, } 2015\end{array}$ & 0.000486 & $9.04 E^{-05}$ & 5.381315 & 0.0000 \\
\hline $\begin{array}{l}\text { The average monthly salary of employees of organizations } \\
\text { (by okved2), ruble, total for the types of economic activity } \\
\text { surveyed, } 2017\end{array}$ & $4.47 E^{-07}$ & $1.17 E^{-07}$ & 3.815645 & 0.0003 \\
\hline
\end{tabular}


Results of the assessment of regression equations for the relative influx of the rural population of the municipality in $2018^{*}$

\begin{tabular}{|c|c|c|c|c|}
\hline \multicolumn{4}{|l|}{ Final sample } & \multirow{2}{*}{$\begin{array}{c}\mathbf{5 9} \\
0.164680\end{array}$} \\
\hline$R$-squared & & & & \\
\hline Adjusted R-squared & & & & 0.150025 \\
\hline$F$-statistics & & & & 11.23731 \\
\hline Prob. (F-statistics) & & & & 0.001429 \\
\hline Variable & Coefficient & Standard error & t-statistics & Prob. \\
\hline$C$ & -0.037749 & 0.006951 & -5.431084 & 0.0000 \\
\hline $\begin{array}{l}\text { The share of the average number of employees (without ex- } \\
\text { ternal part-time workers) of small and medium-sized entre- } \\
\text { preneurs in the average number of employees (without exter- } \\
\text { nal part-time workers) of all enterprises and organizations, } \\
\text { percentage, } 2015\end{array}$ & 0.001045 & 0.000312 & 3.352209 & 0.0014 \\
\hline
\end{tabular}

Table 5

The results of the assessment of regression equations for relative migration growth in urban districts of the Sverdlovsk region*

\begin{tabular}{|c|c|c|c|c|}
\hline \multicolumn{4}{|l|}{ Final sample } & 41 \\
\hline \multicolumn{4}{|l|}{$R$-squared } & 0.705919 \\
\hline \multicolumn{4}{|l|}{ Adjusted R-squared } & 0.663907 \\
\hline \multicolumn{4}{|l|}{$F$-statistics } & 16.80294 \\
\hline \multicolumn{4}{|l|}{ Prob. (F-statistics) } & 0.000000 \\
\hline Variable & Coefficient & Standard error & t-statistics & Prob. \\
\hline$C$ & -0.031605 & 0.003230 & -9.783519 & 0.0000 \\
\hline Number of hospital beds per capita in 2010 & 0.583830 & 0.196797 & 2.966652 & 0.0054 \\
\hline $\begin{array}{l}\text { The share of the average number of employees (without } \\
\text { external part-time workers) of small and medium-sized en- } \\
\text { trepreneurs in the average number of employees (without } \\
\text { external part-time workers) of all enterprises and organiza- } \\
\text { tions in } 2015\end{array}$ & 0.000227 & $7.85 E-05$ & 2.893533 & 0.0065 \\
\hline $\begin{array}{l}\text { The turnover of public catering (excluding small businesses) } \\
\text { (by okved2), thousand rubles per capita, January-Decem- } \\
\text { ber, } 2017\end{array}$ & -0.001455 & 0.000485 & -3.000843 & 0.0049 \\
\hline $\begin{array}{l}\text { The turnover of public catering (excluding small businesses) } \\
\text { (by okved2), thousand rubles per capita, January-Decem- } \\
\text { ber, } 2017\end{array}$ & -0.027018 & 0.010672 & -2.531712 & 0.0160 \\
\hline $\begin{array}{l}\text { Average monthly salary of employees of organizations (by } \\
\text { okved2), ruble, total for the surveyed types of economic ac- } \\
\text { tivity, } 2017\end{array}$ & $6.70 E-07$ & $9.45 E-08$ & 7.089980 & 0.0000 \\
\hline
\end{tabular}

* Compiled by the author.

4. Among health indicators:

- a significant positive effect is exerted by the number of hospital beds per capita in 2010, which confirms the positive contribution of the provision of medical services to reproduction;

- significant negative impact is exerted by the capacity of outpatient organizations, per-shift visits, independent and departments as part of hospital organizations and other healthcare facilities, 2010. The value of this indicator may be explained by the inclusion in the statistics of medical institutions focused on patient care, not living in this municipality.

5. Among the specific indicators of the territory, none had a significant impact.

The results of the assessment of the regression equation are presented in table 5 .

For the share of arrivals from abroad in the total number of arrivals to the municipality in 2018 , none of the factors considered had a significant impact. This circumstance can be ex- plained by the fact that in the case of an influx of people from abroad, the decisive role is played not by local but regional factors of the territory's attractiveness.

The following factors affect the overall mortality rate, per thousand, of 2018 .

1. The average monthly salary of employees of organizations (in okved2), the ruble, in total for the types of economic activity surveyed, 2017, has a negative effect, which confirms a significant positive effect on the reproductive processes of the territory.

2. Among the indicators of social infrastructure, a significant positive effect is exerted by the total area of residential premises, thousand square meters, per capita in 2017. The positive effect of this indicator on mortality can be explained by the elderly living mainly in individual residential buildings, characterized by a larger area per tenant.

3. Among the indicators of economic development of the territory: 
Results of the assessment of regression equations for the overall mortality rate, permille, $2018^{*}$

\begin{tabular}{|c|c|c|c|c|}
\hline \multicolumn{4}{|l|}{ Final sample } & 64 \\
\hline \multicolumn{4}{|l|}{$R$-squared } & 0.502308 \\
\hline \multicolumn{4}{|l|}{ Adjusted R-squared } & 0.468566 \\
\hline \multicolumn{4}{|l|}{ F-statistics } & 14.88682 \\
\hline \multicolumn{4}{|l|}{ Prob. (F-statistics) } & 0.000000 \\
\hline Variable & Coefficient & Standard error & t-statistics & Prob. \\
\hline$C$ & 17.06432 & 1.905956 & 8.953152 & 0.0000 \\
\hline $\begin{array}{l}\text { The share of the average number of employees (without } \\
\text { external part-time workers) of small and medium-sized en- } \\
\text { trepreneurs in the average number of employees (without } \\
\text { external part-time workers) of all enterprises and organiza- } \\
\text { tions in } 2015\end{array}$ & -0.059450 & 0.022832 & -2.603847 & 0.0116 \\
\hline $\begin{array}{l}\text { The total area of residential premises, thousand square me- } \\
\text { ters } m \text {, thousand square meters, per capita in } 2017\end{array}$ & 152.1240 & 65.79641 & 2.312042 & 0.0243 \\
\hline $\begin{array}{l}\text { Capacity of outpatient organizations, per-shift visits, inde- } \\
\text { pendent and departments as part of hospital organizations } \\
\text { and other healthcare facilities, } 2010\end{array}$ & 15.59535 & 5.005596 & 3.115583 & 0.0028 \\
\hline $\begin{array}{l}\text { Average monthly salary of employees of organizations (by } \\
\text { okved2), ruble, total for the surveyed types of economic ac- } \\
\text { tivity, } 2017\end{array}$ & -0.000170 & $2.83 E-05$ & -6.001886 & 0.0000 \\
\hline
\end{tabular}

* Compiled by the author.

Table 7

Assessment results of regression equations for the total fertility rate, permille, $2018^{*}$

\begin{tabular}{|c|c|c|c|c|}
\hline \multicolumn{4}{|l|}{ Final sample } & 64 \\
\hline \multicolumn{4}{|l|}{ R-squared } & 0.590056 \\
\hline \multicolumn{4}{|l|}{ Adjusted R-squared } & 0.562263 \\
\hline \multicolumn{4}{|l|}{ F-statistics } & 21.23055 \\
\hline \multicolumn{4}{|l|}{ Prob. (F-statistics) } & 0.000000 \\
\hline Variable & Coefficient & Standard error & t-statistics & Prob. \\
\hline$C$ & 8.849172 & 0.753251 & 11.74797 & 0.0000 \\
\hline $\begin{array}{l}\text { The number of hospital organizations (departments) of health } \\
\text { care, unit per capita, } 2011\end{array}$ & -15111.39 & 3117.730 & -4.846921 & 0.0000 \\
\hline Number of hospital beds, per capita bed in 2010 & 194.7913 & 66.61007 & 2.924352 & 0.0049 \\
\hline $\begin{array}{l}\text { The share of the average number of employees (without ex- } \\
\text { ternal part-time workers) of small and medium-sized entre- } \\
\text { preneurs in the average number of employees (without exter- } \\
\text { nal part-time workers) of all enterprises and organizations, } \\
\text { percentage, } 2015\end{array}$ & 0.116290 & 0.018861 & 6.165487 & 0.0000 \\
\hline Sown area of crops, hectare per capita, 2017 & 0.924553 & 0.288099 & 3.209148 & 0.0022 \\
\hline
\end{tabular}

- a significant negative effect is exerted by the share of the average number of employees (without external part-time workers) of small and medium-sized enterprises in the average number of employees (without external part-time workers) of all enterprises and organizations in 2015, which also shows the positive impact of the development of small and mediumsized businesses on the state of the territory.

4. Among the indicators of the state of health, a significant positive effect is exerted by the capacity of outpatient organizations, visits per shift per capita, independent and departments as part of hospital organizations and other healthcare facilities, 2010. The value of this indicator may be explained by the inclusion in the statistics of medical institutions, serviceoriented patients who do not live in this municipality.

5. Among the specific indicators of the territory, none had a significant impact.

The results of the evaluation of the regression equation are presented in table 6 .
The following factors influence the total fertility rate, per thousand, of 2018:

1. Wage rates do not have a significant impact on fertility. This conclusion is consistent with the assessment of the regression equation for the proportion of the population younger than working age and indicates that other factors have a greater influence on the decision to give birth to children.

2. Among indicators of social infrastructure, not one indicator has a significant impact on fertility.

3. Among the indicators of economic development of the territory:

- a significant positive impact is exerted by the share of the average number of employees (without external part-time employees) of small and medium-sized enterprises in the average number of employees (without external part-time workers) of all enterprises and organizations in 2015, which also shows the positive impact of the development of small and mediumsized businesses on the state of the territory; 
Results of the assessment of regression equations for the share of those who leave outside the Russian Federation in the total number of people who left the municipality in $2018^{\star}$

\begin{tabular}{|c|c|c|c|c|}
\hline \multicolumn{4}{|l|}{ Final sample } & 63 \\
\hline$R$-squared & & & & 0.243266 \\
\hline Adjusted R-squared & & & & 0.191078 \\
\hline F-statistics & & & & 4.661298 \\
\hline Prob. (F-statistics) & & & & 0.002485 \\
\hline Variable & Coefficient & Standard error & t-statistics & Prob. \\
\hline$C$ & -0.081578 & 0.032910 & -2.478783 & 0.0161 \\
\hline $\begin{array}{l}\text { Pollutants emitted from stationary sources into the atmo- } \\
\text { sphere - total, thousand tons per capita, } 2017\end{array}$ & -0.002261 & 0.001273 & -1.776842 & 0.0808 \\
\hline MDOU attendance rate, percent, 2011 & 0.121267 & 0.042251 & 2.870168 & 0.0057 \\
\hline Number of sports facilities, total, unit per capita, 2017. & -5.894087 & 3.254908 & -1.810831 & 0.0753 \\
\hline $\begin{array}{l}\text { The average monthly salary of employees of organizations } \\
\text { (by okved2), ruble, total for the types of economic activity } \\
\text { surveyed, } 2017\end{array}$ & $1.04 E^{-06}$ & $4.58 E^{-07}$ & 2.267573 & 0.0271 \\
\hline
\end{tabular}

Results of the assessment of regression equations for the share of those who leave within the region in the total number of people who leave the municipality in $2018^{\star}$

\begin{tabular}{|c|c|c|c|c|}
\hline \multicolumn{4}{|l|}{ Final sample } & 64 \\
\hline$R$-squared & & & & 0.293974 \\
\hline Adjusted R-squared & & & & 0.258672 \\
\hline$F$-statistics & & & & 8.327552 \\
\hline Prob. (F-statistics) & & & & 0.000103 \\
\hline Variable & Coefficient & Standard error & t-statistics & Prob. \\
\hline$C$ & 0.957516 & 0.070913 & 13.50277 & 0.0000 \\
\hline Number of hospital beds, per capita bed in 2010 & -14.30017 & 5.024344 & -2.846176 & 0.0060 \\
\hline Number of cultural and leisure facilities, unit per capita, 2017 & 194.1063 & 109.2018 & 1.777500 & 0.0806 \\
\hline $\begin{array}{l}\text { The average monthly salary of employees of organizations } \\
\text { (by okved2), rubles, total for the types of economic activity } \\
\text { surveyed, } 2017\end{array}$ & $-6.20 E^{-06}$ & $1.94 E^{-06}$ & -3.188386 & 0.0023 \\
\hline
\end{tabular}

* Compiled by the author.

- significant positive effect is exerted on the sown area of crops, hectare per capita, 2017. The value of this indicator indicates the positive impact of agricultural development on the birth rate.

4. Among the indicators of the state of health:

- a significant positive effect is exerted by the number of hospital beds, the bed per capita in 2010;

- significantly negative effect is exerted by the number of hospital organizations (departments) of health care, unit per capita, 2011.

These indicators together indicate a positive effect of the state of health on fertility, however, as well as in the case of estimates for the proportion of the population younger than working age, they indicate the characteristics of the demand for medical services.

5. Among the specific indicators of the territory, none had a significant impact.

The results of the evaluation of the regression equation are presented in table 7 .

The following factors influence the share of those who leave within the region in the total number of people who leave the municipality in 2018.

The following factors influence the share of those who leave outside the Russian Federation in the total number of people who leave the municipality in 2018:
1. The average monthly salary of employees of organizations (by okved2), the ruble, total for the types of economic activities surveyed, 2017 has a negative effect, which confirms the conclusion about the positive effect of wages on retention and is consistent with conclusions regarding migration factors outside the Russian Federation.

2. Among the indicators of social infrastructure, a significant positive effect is exerted by the number of cultural and leisure institutions, unit per capita, 2017.

3. Among the indicators of economic development of the territory, none has a significant impact.

4. Among the indicators of the state of health care, a significant negative effect is exerted by the number of hospital beds, bed per capita in 2010, which is generally consistent with estimates of other regression equations and characterizes the positive impact of health on population reproduction.

5. Among the specific indicators of the territory, none has a significant impact.

The results of the evaluation of the regression equation are presented in table 9.

The following factors influence the share of those who leave outside the Russian Federation in the total number of people who leave the municipality in 2018:

1 . The average monthly salary of employees of organizations (okved2), the ruble, in total for the types of economic 
activity surveyed, 2017, has a positive effect, which can be explained by the peculiarities of population migration strategies. Since migration entails significant costs associated with moving and settling in a new place of residence, people migrate only if it gives them a significant increase in income. In this case, it turns out that residents of low-wage territories can benefit from migration when moving within the region, while residents of high-wage territories can get the required return only with a more radical change of place of residence, in particular moving abroad .

2. Among the indicators of social infrastructure:

- a significant negative impact is exerted by the number of sports facilities, in total, unit per capita, 2017;

- a significant positive effect is exerted by the attendance rate of MDOU, percent, 2011.

3. Among the indicators of economic development of the territory, none has a significant impact.

4. Among the indicators of the state of health, not one indicator has a significant effect.

5. Among the specific indicators of the territory, a significant negative impact is exerted by the indicator emitted into the atmosphere of pollutants emanating from stationary sources - total, thousand tons per capita, 2017.

The results of the evaluation of the regression equation are presented in table 8 .

\section{Discussion and Conclusion}

In general, the following conclusions can be drawn from the results of the pilot study.

A significant effect of wage indicators on some key parameters of reproduction was found. These include: the proportion of the working-age population in the total population, the general influx of the population, migration growth, the overall mortality rate, and indicators of the structure of the migration outflow. Moreover, for all indicators except indicators of the structure of the migration outflow, the explanatory ability of the model turned out to be sufficiently high for spatial data, which allows it to be used in predicting the reaction of the re- production of labor resources to changes in the level of wages in the territory.

The impact of wage indicators on fertility indicators, the share of the population below working age and the relative outflow of the rural population was not found. It was also not possible to identify the factors of migration attractiveness of the territory for visitors from abroad, as well as the proportion of the population older than working age.

There is also a significant impact on the indicators of reproduction of health indicators in the territory. At the same time, for some regression equations, the effect is quite contradictory, which can be explained by the peculiarities of the organization of the healthcare system in the territory, the peculiarities of millet for medical services, the insufficient relevance of the data, or the poor choice of explanatory variables. In any case, the inclusion of health indicators in the analysis of reproductive processes seems necessary. Moreover, on the basis of the analysis, it is possible to give a recommendation to the territorial statistical authorities on the return of indicators of the health system to the indicator system of municipalities.

You can also give a recommendation on the inclusion in the system of indicators of municipalities indicators of the educational level of the population. In fact, at the moment, these indicators are available only on October 17, 2010, which does not allow them to be used in the study. In our opinion, the lack of data on the educational level of the population of municipalities makes it difficult to assess the impact of the introduction of professional standards on the reproduction of the labor resources of the territory, since one of the main requirements for personnel fixed by professional standards is the requirement for the level of education.

In the future, it is proposed to expand the pilot project for assessing the impact of wages on the reproduction of the labor resources of the territory by including in the analysis data on municipalities of the Ural economic region and using various types of data in the analysis, including panel data.

\section{References}

1. Taylor H. C. An introduction to the study of agricultural economics. London: The Macmillan \& Co ltd, 1912.327 p.

2. Ardington C., Menendez A., Mutevedzi T. Early Childbearing, Human Capital Attainment, and Mortality Risk: Evidence from a Longitudinal Demographic Surveillance Area in Rural KwaZulu-Natal, South Africa [e-resource] // Economic Development and Cultural Change. 2015. Vol. 63. No. 2. Pp. 281-317. URL: www.jstor.org/stable/10.1086/678983.

3. Ma S., An S., Park D. Urban-Rural Migration and Migrants' Successful Settlement in Korea [e-resource] // Development and Society. 2018. Vol. 47. No. 2. Pp. 285-312. URL: www.jstor.org/stable/90022841.

4. Dutta S., Subhendu C. Rural-Urban Linkages, Labor Migration \& Rural Industrialization in West Bengal [e-resource] // Indian Journal of Industrial Relations. 2015. Vol. 50. No. 3. Pp. 397-411. URL: www.jstor.org/stable/24549103.

5. Luong Hy V. The Changing Configuration of Rural-Urban Migration and Remittance Flows in Vietnam [e-resource] // Sojourn: Journal of Social Issues in Southeast Asia. 2018. Vol. 33. No. 3. Pp. 602-646. URL: www.jstor.org/stable/26538280. 6. Sagynbekova L. Environment, Rural Livelihoods, and Labor Migration: A Case Study in Central Kyrgyzstan [e-resource] // Mountain Research and Development. 2017. Vol. 37. No. 4. Pp. 456-463. URL: www.jstor.org/stable/90016611.

7. Zakshevsky V. G., Merenkova I. N. Sotsial'no-ekonomicheskie usloviya formirovaniya chelovecheskogo kapitala sel'skikh territoriy [Socio-economic conditions for the formation of human capital in rural areas] // Ekonomika, trud, upravlenie $\mathrm{v}$ sel'skom khozyaystve. 2019. No. 4 (49). Pp. 2-8. (In Russian.)

8. Gorbunova O. S. Formirovanie chelovecheskogo kapitala agrarnoy sfery regiona: dis. ... kand. ekon. nauk [The formation of human capital in the agricultural sector of the region: the dissertation for the degree of candidate of economic sciences]. Ekaterinburg, 2018. 206 p. (In Russian.)

9. Yugov E. A. Problemy vosproizvodstva trudovykh resursov sel'skoy mestnosti [Problems of reproduction of labor resources in rural areas] // Vestnik of Kursk State Agricultural Academy. 2018. No. 4. Pp. 191-197. (In Russian.) 
10. Yurzina T. A. Egorova N. N., Zaruba N. A., Kosinskiy P. D. Otsenka vliyaniya trudovykh resursov na razvitie sel'skikh territoriy Kemerovskoy oblasti [Assessment of the impact of labor resources on the development of rural areas of the Kemerovo region] // Economics and Innovation Management. 2018. No. 3. Pp. 9-16. (In Russian.)

11. Bannikova N. V., Sidorova D. V., Astrakhantseva E. Yu. Kompleksnaya otsenka programmnogo regulirovaniya usloviy vosproizvodstva trudovykh resursov sel'skikh territoriy [A comprehensive assessment of the program regulation of the conditions for the reproduction of labor resources in rural areas] // Bulletin of NSAU. 2017. No. 4 (45). Pp. 172-183. (In Russian.)

12. Bondarenko L.V. Sotsial'noe razvitie sel'skikh territoriy: problemy i perspektivy [Social development of rural territories: problems and prospects] // Agroprodovol'stvennaya politika Rossii. 2017. No. 4 (64). Pp. 13-18. (In Russian.)

13. Rakhmatullina L. I. Vosproizvodstvo trudovykh resursov v sel'skom khozyaystve: dis. ... kand. ekon. nauk [Reproduction of labor resources in agriculture: the dissertation for the degree of candidate of economic sciences]. Orenburg, 2017.212 p. (In Russian.)

14. Umerova S. E. Utochnenie struktury i sposob otsenki kharakteristik trudovykh resursov primenitel'no k naseleniyu sel'skikh territoriy [Clarification of the structure and method for assessing the characteristics of labor resources in relation to the population of rural areas] // Zakonomernosti razvitiya regional'nykh agropromyshlennykh sistem. 2017. No. 1. Pp. $201-204$. (In Russian.)

15. Chelovecheskiy potentsial sel'skikh territoriy v period sotsial'no-ekonomicheskikh transformatsiy: otchet o NIR (zaklyuch.) [The human potential of rural territories during the period of socio-economic transformations: report on research (conclusion)] / Head E. A. Chekmareva, executors K. A. Ustinova, T. N. Likhacheva, K. N. Kalashnikov. Vologda, 2017.116 p. (In Russian.)

16. Sharipov S. A. Rost narodonaseleniya i formirovaniya trudovykh resursov sel'skikh territoriy [The growth of population and the formation of labor resources in rural areas] // Agroprodovol'stvennaya politika Rossii. 2017. No. 1 (61). Pp. 10-17. (In Russian.)

\section{Authors' information:}

Valentina M. Sharapova ${ }^{1}$, doctor of economics, professor of the department of accounting and audit, ORCID 0000-0003-1272-827X, AuthorID 477919; + 7 (343) 21-41-39

Ivan A. Borisov², senior lecturer, department of political economy, ORCID 0000-0002-0450-1342, AuthorID 243683; +7 (343) 221-27-52

Natalya V. Sharapova ${ }^{2}$, candidate of economic sciences, associate professor, department of management and entrepreneurship, ORCID 0000-0002-5247-0683, AuthorID 627402; +7 (343) 283-10-53, sharapov.66@mail.ru

${ }^{1}$ Ural State Agrarian University, Ekaterinburg, Russia

${ }^{2}$ Ural State Economic University, Ekaterinburg, Russia 